821.163.41.09-1 Лалић И. В. https://doi.org/10.18485/kij.2021.68.1.9

ЈАНА С. ПЕТРОВИЋ, студент основних студија* Универзитет у Београду

Филолошки факултет
Оригинални научни рад

Примљен: 29.03.2021.

Прихваћен: 26.04.2021.

\title{
ПОЕТСКА ЕВОКАЦИЈА ДУБРОВНИКА У ПЕСНИЧКОМ ЦИКЛУСУ ДУБРОВНИК - ЗИМСКА ПРИЧА ИВАНА В. ЛАЛИЋА
}

\begin{abstract}
У раду се анализирају поступци којима Иван В. Лалић евоцира књижевно, културно и историјско наслеђе старог Дубровника у циклусу Дубровник-зимска прича, као и смисао и функција коју призвана баштина задобија у свакој од песама. Лалићево ступање у дијалог са дубровачком традицијом сагледава се у контексту побуђеног интересовања српских писаца XIX и XX века за Дубровник и његово наслеђе.
\end{abstract}

Кључне речи: Иван В. Лалић, Дубровник - зимска прича, Дубровник, српска књижевност XIX века, српска књижевност XX века, дубровачка књижевност, култура.

Проучаваоци су издавна препознали Ивана В. Лалића као „мајстора дијалога” (Делић 2007: 57) и ствараоца „који је у своју одабрану традицију укључио целину српске књижевности" (Алексић 2015: 221). У песниковом опусу издваја се и поетска евокација дубровачке културне и књижевне баштине, а интересовањем за овај слој традиције Лалић се надовезује на постојану струју српских стваралаца за које су стари Дубровник и дубровачка књижевност представљали непресушно врело поетске инспирације.

О високом месту које Град Светог Влаха заузима у српској књижевности сведочи не само чињеница да се у усменој традицији често представљао као „симбол изобиља, раскоши и господства” (Петаковић 2012: 124) већ и то што су његово књижевно и културноисторијско наслеђе, у XIX и XX веку, надахнули ауторе различитих уметничких проседеа. Наслеђе дубровачке књижевности и прошлост Града инспирисали су лирску и епску поезију Јевтимија Поповића (в. Бојовић, 1983: 248-249), Јована Илића (в. Мартиновић 1938: 299-301), Петра II 
Петровића Његоша (Бојовић 1983: 258) и Бранка Радичевића (в. Вуловић 1890: 136-138), а почетком XX века и спев Слике са Јадрана Милана Савића (в. Бојовић 1997: 109-114), поезију Алексе Шантића (в. Летић 2000: 113-142) и Јована Дучића. „Дубровачке теме” окупирале су и прозне ствараоце, па су, након историјских приповедака Стевана Сремца (в. Летић 2005: 177-184), прошлост Града оживели разнородни записи Андре Гавриловића (Бојовић 2007a: 139-146), историјске приповетке Милана Савића (в. Бојовић 1997: 109-114) и Вида Вулетића Вукасовића (Бојовић 2009а: 189-196), романи Душана Богосављевића (в. Бојовић 1996б:129-137), Александра Видаковића (в. Бојовић 2007б: 239-247) и других. Историјска грађа била је основа драме Маројища Кабога Матије Бана (в. Бојовић 1996в: 77-85), потом дела Андре Гавриловића (Бојовић 2007а: 139146), Николе Ђурића (в. Бојовић 2009б: 137-146) и бројних других драмских стваралаца.

Интересовање за прошлост Дубровника проналазило је одјека и у историографском раду књижевних стваралаца. Јован Дучић периодима боравка Саве Владиславића у Дубровнику посвећује значајно место у својој монографији о овом дипломати (в. Бојовић 1996а: 193-200), а историјским личностима из дубровачке прошлости бавио се и Иво Андрић (в. Бојовић 1994: 255-267).

Упоредо са фикцијским и нефикцијским остварењима у којима су се ствараоци ослањали на различите аспекте дубровачког наслеђа, настајала су и њиме надахнута дела путописне књижевности. Тако се између 1895. и 1903. године појављује читав низ путописа (в. Петаковић: 2016б: 353-364) који, уз промишљања о Граду која је у своје путописне и есејистичке текстове уносио Милош Црњански (в. Бојовић 2005б: 167-174), сведоче о томе да, у периоду коначног формирања књижевног система српске књижевности, постоји живо интересовање за Дубровник. Исту поетичку линију настављају и есеји Луја Војновића из књиге Кюижевни часови, који представљају прошлост Града као „споменик вишевековне историје, али и митопоетско чвориште" (Петаковић 2017 : 66), чиме се директно надовезују на његове четрнаест година раније објављене Дубровачке елегије, прозаиде у којима је дескрипција пејзажа „преломљена кроз ауторову психолошку оптику" (Петаковић 2016а: 102). На сличан начин Град представља и Иво Војновић у својим Лападским сонетима. Прожимајући слике предела реминисценцијама, и овај је песник, на трагу свога претходника, створио двоструку слику појавног и метафизичког Града (Петаковић 2016а: 104).

Оваква двострукост приказивања појавног света, који представља само подстицај за тражење смисла који се налази иза видљивог, поетичка је константа и песничког опуса Ивана В. Лалића (Јовановић 1997: 14). У том смислу, његов циклус Дубровник - зимска прича представља спонтан продужетак линије поетског евоцирања наслеђа Старог Дубровника коју су трасирали Лујо и Иво Војновић. ${ }^{1}$

${ }^{1} \mathrm{O}$ томе да је Лујо Војновић схватао историју и њене материјалне трагове као нешто иза чега се назире метафизичка суштина ствари, сведоче не само његове песме у прози и есеји већ и његове 
Песме обухваћене овим циклусом објављене су у часопису Кюижевност, 1967. године, поводом тристагодишњице земљотреса који је 1667. године разорио Дубровник. ${ }^{2}$ Истом пригодом, у овом броју часописа појавио се и текст драме Кључеви Светог Влаха, Љубомира Симовића. ${ }^{3}$ Поетички и жанровски по много чему различита, ова дела, осим пригоде, имају још једну заједничку карактеристику: као и Лалић, и Симовић „контекстуализује наслеђено не повређујући његов поетски хабитус" (Петаковић 2020: 781).

Контекстуализацији онога наслеђеног из старог Дубровника Лалић, ипак, прилази и стваралачки, а само наслеђе третира слободно, подразумевајући под својим предтекстом „мање или више: од једне синтагме, стиха, мотива, до књижевности читавог једног раздобља" (Шеатовић-Димитријевић 2007: 139). У том смислу, оно што се у компаратистичкој терминологији означава као невербални текст културе (в. Константиновић 2002: 8-11), најплодоноснији је извор цитата у овом циклусу.

Већ сам његов наслов - Дубровник - зимска прича - открива да Град има посебно место у песниковом опусу. Наиме, због прожимности мотива најтоплијег годишњег доба у Лалићевом опусу, он се неретко карактерише као „песник лета" (в. Јовановић 1996: 97-112). Лето пак у његовој поезији није пука синегдохска ознака природног циклуса, већ добија значење времена самог (Јовановић 1997: 52). Осим тога, Средоземље, у чијем се басену и културном кругу налази и Дубровник, најчешћа је „географска локација” у Лалићевој поезији (Христић 1994: 99). Како је лето типичан елемент иконографије медитеранског простора, увођење мотива зиме у наслов циклуса изневерава очекивања читаоца упознатог са песниковим особеним системом симбола, те сугерише изузетост Дубровника из законитости протицања времена, у чијем кретању нужно долази до пропадања свих видљивих ствари. Извор „отпорности” коју Град у Лалићевој песничкој имагинацији ужива спрам трошности осталих тековина материјалне култуpe, можда се може потражити управо у пригоди која је била подстицај за настанак ових песама. Наиме, свест о томе да је разорени ренесансни град обновљен, да је „преживео” и поново се родио у свом барокном лику, доводи до његовог имагинирања као простора у којем је време заустављено. Зато су стварносни локалитети са којих се лирски субјекат упућује у онострано путовање метафизичким градом неретко управо они који су на неки начин чудесно преживели „Велику трешњу”.

Као простор који није изузет из природних процеса који прате протицање времена, али у којем је, парадоксално, све и одолело зубу времена, Дубровник је

речи упућене читаоцима на почетку Кратке историје Дубровачке републике, којима аутор наглашава да „историја није мртва ствар ни скуп материјала, него ускрснуће” (в. Војновић 1962: 5).

${ }^{2}$ На овај јубилеј као највероватнији повод настанка циклуса указала је Злата Бојовић (в. Бојовић 2005а: 367-373).

${ }^{3}$ Да и Симовић припада низу стваралаца XX века који су баштинили културноисторијско и књижевно наслеђе Дубровника као своју одабрану традицију сведочи његов роман Ужице са вранама, али и његова поетска и есејистича дела (в. Бојовић 2001: 49-62). 
представљен већ у првој песми циклуса, која носи наслов Путник пред Дубровником, јануара. На особеност простора указује мотив јануара (зиме), а његов тријумф над пролазношћу сугерише и слика зидина Града као круне времена. На трагу путописаца краја XIX и почетка XX века, повлашћено место дато је тренутку ступања песничког субјекта у Дубровник (Петаковић 2016б: 354), што подразумева сусрет са призором градских зидина - најуочљивијим елементом дубровачке ведуте. Није, међутим, случајно што управо слику градских зидина виђених с мора, која отвара Лалићев циклус, находимо и у првој прозаиди Војновићевих Дубровачких елегија (в. Војновић 1924: 11-12). Будући да су у песми бедеми представљени као „Венац камени разуђен / На глатком челу векова” (Лалић 1968: 57), зидине у Лалићевој поетској имагинацији постају круна времена, синегдохски означеног „вековима”. На смисао песничке слике градске утврде надовезује се последња слика у песми, која још јасније указује на изузетно место Дубровника у Лалићевом стваралаштву. Наиме, док „видљиве” тековине културе по правилу представљају „огледало пролазности” (в. Микић, 1996: 90), те разоткривају вечну динамику која доводи до неизбежног пропадања цивилизација, стари Дубровник, „град у прстену кула” „нишан” је Зенонове стреле (Лалић 1968: 57). Овом метафором, материјална култура Града доводи се у везу са чувеном апоријом хеленског филозофа, према којој кретање представља збир мировања у различитим тачкама. Тиме се материјални Град представља као видљиво сведочанство протока времена и одолевања пролазности, по много чему другачије од других видљивих трагова прошлости. - Док нестанак локалитета попут Смедерева сведочи о динамици, у којој појавно неминовно престаје да постоји, и метафизичком смислу несталог, који надживљава материјално (Јовановић, 1997: 22-23), стари Дубровник представља склад постојаности и материјалног и духовног аспекта историје, јер су чак и тековине његове материјалне културе преживеле велики земљотрес и наставиле да трају и у историјском и у метафизичком виду. У том смислу, иако подложан динамици дијахронијских процеса, попут одапете стреле у лету, Дубровник остаје и статичан у окамењености своје архитектонске и духовне баштине.

Како у песми Писар нема упадљивих реминисценција на конкретно културносисторијско наслеђе Града, а мотиви писма, писања, па и писара, спадају у ред оних који прожимају читав Лалићев опус, она, наизглед, спада у оне текстове који су у одређени циклус увршћени искључиво преко наслова наджанровске целине. Међутим, помно читање указује на то да име надређене структуре није једини чинилац обједињавања ове песме у јединствену целину са осталим текстовима из циклуса Дубровник - зимска прича. Уколико се има у виду да Дубровник данас располаже једним од најбогатијих архива у Европи, благодарећи административној педантности која је негована у Републици Светог Влаха, указују се снажније споне између главног мотива песме и историјског наслеђа Града. У оваквој констелацији ствари, одређени елементи слике писара у овој песми могу се протумачити као још један вид евоцирања књижевног наслеђа старог Дубровника. Наиме, „Зрикавац који се јавља / гласом врелог гвожђа кад 
додирне воду” (Лалић 1968: 58), примарно је онеобичена представа звука који производи овај инсект, али се на секундарном семантичком плану у њему може крити и суптилна алузија на мотив зрикавца, односно шттурка, који се јавља у поезији Мавра Ветрановића, те у имену барокне „Академије Штурака”, „књижевне дружине" Франа Геталдића Крухорадића и Антуна Глеђевића (в. Бојовић 2014: 403, 405). С обзиром на то да није могуће Лалићеву песму довести у чврићу везу са Ветрановићевом побожном Пјесанцом штурку, као ни са деловањем поменутог удружења ерудита, овако протумачена алузија тек је далеки одјек чињеница из књижевне прошлости Дубровника. Неупадљив и пропуштен кроз сито поетике Ивана В. Лалића, у којој се из традиције преузимају садржаји, али по правилу не и лексика (в. Јовановић 1997: 10-11, 76-77), означитељ „зрикавац” се тек довођењем у везу са речју „штурак” може разумети као суптилна алузија на књижевни живот Града.

Наслов песме Гласови: Finis reipublicae наговештава са којим ће традицијама овај текст ступити у најживљи итертекстуални дијалог: гласови, као „симбол за претке уопште” (Алексић 2015: 218) сугеришу пројављивање фолклорне традиције, док устаљена латинска синтагма која се везује за пропаст Дубровачке републике алудира на истим речима насловљен прилог Луја Војновића, ${ }^{4}$ објављен 1907. године у Савременику, и тако повезује Лалићеву песму и са нефикцијском књижевношћу почетка XX века и опусом овог аутора. Ове традиције повезане су пак, на особен начин, са наслеђем старог Дубровника.

Облик множине у латинском делу наслова песме издиже повесни догађај на који се односи - укидање Дубровачке републике - изнад равни појединачног и историјског, и поставља га на ниво панхроничног, метафизичког збивања. Отуда у последњој строфи Лалићеве песме, стиче се утисак, у првом лицу множине проговарају „гласови” колектива разорене државе. Иако се „преживљавање” гласова одвија у „подневу пораза” (Лалић 1968: 59, курзив - Ј. П.), мотив Сунчевог зенита сугерише тријумфалну позицију, а семантика читаве песме упућује на претрајавање баштине ,златног доба” Града као на победу метафизичког смисла, симболички представљеног гласовима наслеђа, над политичком пропашћу. Међутим, није само евокација историјског наслеђа старог Дубровника прожета дијалогом Лалићеве поезије са промишљањима Луја Војновића: осим што отвара хоризонт очекивања за интертекстуалне везе са усменом традицијом, мотив гласова повезује ову песму и са Војновићевим прозаидама. У низу његових Дубровачких елегија, овај се мотив јавља уз нуминозно осећање присуства нечега иза појавног. Тако гласови, у песми На Локруму, у море „слазе као (...) праведници у Видјело Вјечности" (Војновић 1924: 76, курзив - Ј. П.) и тријумфују над пролазношћу на исти начин као и они из песме Гласови: Finis reipublicae.

Усмена традиција јавља се у овој песми „на нивоу језичко-стилских средстава" (Алексић 2015: 219). У том смислу, мотив браве из друге строфе, може се, осим као суптилна културноисторијска алузија, протумачити и као један вид

\footnotetext{
${ }^{4}$ Пун наслов прилога гласи „Finis reipublicae (31. јануара 1808)”.
} 
цитирања народне традиције. Говор представљен као „опточен мутним златом седам брава”, и као да истовремено „каже јесте и (...) каже није” (Лалић 1968: 59), указује на природу дипломатског дискурса Републике Светог Влаха, ${ }^{5}$ те се препознаје као једна од дубровачких реалија. Истовремено, у фолклорном фонду сусреће се мотив чудесне браве дубровачке, надалеко чувене са лепоте занатске израде и „високе сигурности” (Петаковић 2013: 34), па се кроз њега прелама замршен и вишегласан Лалићев дијалог са наслеђем материјалне културе Града и усменом књижевношћу.

Како је поморска трговина била стуб економске стабилности Дубровника, и песма Морнарица укључује се у ред оних које већ својим насловом евоцирају историјско наслеђе Града Светог Влаха. На трагу дубровачких ренесансних песника који су трговачкој флоти придавали оностране квалитете, сликајући је као предвођену самим Светим Влахом (Галијун, Мавра Ветрановића) или је поредећи са космолошким и митским ентитетима, попут звезде Данице или косе „горске виле” (Мрнарища, Антуна Сасина), и Лалић, „наглашавајући да се уместо морем, плови временом (...) прецизира да је оностраност место бивствовања гласа”, те показује да се „дубровачка морнарица, као и књижевност, преселила (...) у трајање с оне стране, као део (...) традиције” (Алексић 2015: 220). У том смислу, стихови у којима се наводи да, на оној страни ваздуха на којој обитава дубровачка морнарица, „нема обала”, већ само „реч по која” (Лалић 1968: 60, курзив - Ј. П.), разоткривају имплицитну поетику ове песме. - Непосредна веза са књижевном традицијом у њој је остварена тек рефренским понављањем речи „галијун” (Алексић 2015: 220), и речју „морнарица”, као „сећањем сведеним на сигнал” (Лалић 1968: 60), јер се везе са Ветрановићевом и Сасиновом песмом отварају превасходно у рецепцијској сфери, активиране тек лексиком као индикатом, сигналом да су ове речи некада биле означитељи лајтмотива антологијских дела дубровачке књижевности.

Песма Онофрио алудира на Велику и Малу Онофријеву чесму, које стоје на почетку и крају Плаце, главне градске улице, те се и убрајају међу најзначајније локалитете у старом градском језгру. Ови споменици материјалне културе ренесансе носе име италијанског архитекте који је у XV веку израдио пројекат градске водоводне мреже, доделивши великој чесми симболички смисао крстионице, а малој посуде за свету воду. Тиме је тлоцрт града, у његовој замисли, постао нацрт „замишљене цркве” (Новак 2005: 13). Будући да у овој песми до изражаја долази „отклон од субјективности и заклањање маском” (Веселиновић 2012: 172), она је двострукошћу обележена не само у погледу несигурности у вези са тим која од двеју чесми представља подстицај певања, већ и у погледу могућности за интерпретацију „идентитета” лирског субјекта. Наиме, глас не-

${ }^{5}$ На пословични стилски рафинман дубровачке дипломатске преписке и тенденцију Републике да свој спољнополитички положај осигурава обећавајући исте ствари великим силама, чак и када су њихови интереси супротстављени, указао је Лујо Војновић у Краткој историји Дубровачке републике, наглашавајући да „нема државе (...) која је плаћала више ријечима од Дубровника” (Војновић 1962: 53). 
одређеног песничког ,ја” које путује градом, испреплетен је са гласом који носи маску самог градитеља, а могуће је разумети га и као „проговарање” било које од двеју епонимски означених чесми. Ове интерпретативне могућности отвара синтагма „игра мојих капљица” (Лалић 1998: 61, курзив - Ј. П.). Двострукост се прво разрешава ,у корист” људских ентитета, с обзиром на то да се „игра капљица" већ у наредном стиху лирским паралелизмом доводи у везу са метафором „мог сна сведеног на закон” (Лалић 1998: 61), па се у том сну може препознати градитељева замисао о сакрализацији простора града његовим симболичким претварањем у цркву. Ипак, посматрач „глава рошавих образа” (Лалић 1998: 61), које, по свему судећи, реферишу на рељефе на чесмама, равноправно могу бити и Онофрио у историјском, и лирски путник у метафизичком, доживљеном времену. Трећа строфа, која говори о „невидљивим вртовима ваздуха насељеним после жубора” (Лалић 1998: 61), укида пак ову двострукост, те се лирско „ја” недвосмислено изједначава са песничким ,jа”: једино песничко ,ја” може те, оностране вртове, као просторе метафизичког путовања и сусрета са одсутном традицијом, актуализовати „после жубора” (курзив - Ј. П.), тј. после доживљавања предметне стварности, остајући у дијалогу са њима и након физичког удаљавања.

Поступак креирања „маске” доследно је примењен у песми Свети Влахо. Већ у првој строфи, у којој се лирски субјекат у првом лицу једнине представља као „светац (...) што улази(м) у сан, гласник оружја / Што буди кресте ватре на бедемима / У једној зори смрзнутој у предање” (Лалић 1968: 62), разоткрива се да је управо светац-заштитник Дубровачке републике маска песничког ,ја” у овом тексту. Сликање спољње претње, уобличено исказима у презенту тако да одаје утисак симултаности збивања и говора лирског субјекта, поступак је који је у обликовању истог мотива применио и Лујо Војновић, у прозаиди која такође носи наслов Свети Влахо (в. Војновић 1924: 21-23). Предање које се призива наведеним стиховима објашњава начин на који је светитељ стекао статус заштитника града: јавивши се једном свештенику у сну и упозоривши га на намеру Млетака да нападну град, Свети Влахо указао је на изненадну опасност и тиме постао бранитељ државе. Тек се првим стихом друге строфе лапидарно указује на изворну, хагиографску причу, да би у остатку песме главна тема остао начин на који је култ Светог Влаха живео у Дубровнику. Тако Лалић, певајући о томе како је „Лекар из Кападокије, мученик / Размножен на свим морима у орнату, / Као толико златника у горкој ковници” (Лалић 1968: 62), алудира на дубровачки новац са представама овог светитеља, а сликом Светог Влаха као „обневиделог ту, на зидинама, где плашт му од камена кројише с љубављу” (в. Лалић 1968: 62) евоцира чињеницу да су кипови овог светитеља клесани у камену на свим градским тврђавама.

Од свих текстова из циклуса Дубровник - зимска прича, песма Каменари на најочигледнији начин призива пригоду која је надахнула њихов настанак. У том смислу, основни текст цитиран у овој песми јесте невербални текст културе у којој је „Велика трешња” остала упамћена као историјски међаш и раздеона ли- 
нија „златног доба” републике на време пре и после 1667. године. Зато, по свему судећи, није случајно ни то што је она, у циклусу који броји дванаест песама - седма по реду: песма Каменари стоји на почетку друге половине колоплета песама инспирисаних Дубровником, као што историјски догађај који евоцира стоји на почетку барокног раздобља у култури Града. Из позиције колективног субјекта поетског говора - каменорезаца, одн. каменара, пева се о „осовљавању” речи у ваздуху и превођењу „незнаног језика у ликове знане”, као о „прећутном споразуму са јачом мером твари” (в. Лалић 1968: 63, курзив - Ј. П.). На овај начин, у песми се настанак материјалних аспеката града представља као отеловљење онога неопипљивог, метафизичког, што је оличено у метафорама језика и гласа. Следствено томе, и нестанак тих, материјалних трагова културе, до којег долази онда када „(..) се земља затресла”, у вези је са језиком „(...) што се стапа / С почетком” (Лалић 1968: 63). У том смислу, мотив обнове града, похрањен у стихове „Кад се осушила крв / Покушали смо опет”, сугерише да је обнова зидина нераскидиво повезана са „обновом” говора. Тиме се догађај из прошлости доводи у везу са синхронијом, у којој се онтолошки смисао Града такође обнавља у говору - безгласним „обраћањем” песничком ,jа” које ослушкује традицију и преноси одјеке дијалога са њом. У том смислу, овај поетски текст није само по свом положају у следу песама са „дубровачким темама” чворна тачка Лалићевог циклуса. Он је и главни пункт представљања Дубровника као ентитета који одолева разорној снази историјског пропадања, остајући нетакнут, не само у постојаности свог обновљеног материјалног „лика” већ и у виталности своје баштине у култури јужнословенских народа.

Размишљања о порукама скривеним иза појавног, у песми Дубровачке зидине, дата су у форми посланице - једне од типичних песничких врста дубровачке књижевности. У духу конвенција овог жанра, лирски субјекат обраћа се непознатом адресату, реферишући, најпре, на садржај претходне „кореспонденције”, која за предмет има одређено стварносно искуство - у овом случају имплицирано уводним стихом „Писао сам ти о шетњи” (Лалић 1968: 64). Међутим, песма одступа од наредне важне жанровске особености посланице: након упућивања на садржаје раније комуникације, она не пружа нова „обавештења”. Читав текст евокација је претходног писаног „разговора”, те, у том смислу, предмет саопштавања у Лалићевој постсимболистичкој посланици постаје - саопштавање само. Адресант, дакле, упућује посланицу којом саопштава да је нешто већ саопштио. Сасвим у духу модерне поезије, то већ исказано искуство - искуство је шетње градом која, будући рефлекс мотива путовања, духовно оплемењује лирског субјекта. У опис овакве шетње просторима видљивог, Лалић је унео реалије дубровачке топографије, те се у представљању проласка зидинама помињу имена кула Асимон, Мртво Звоно, Калариња и Дрезвеник. Поред материјалне културе, песнички ће субјекат евоцирати и историјске чињенице из дубина прошлости. Слично као што се дубровачка морнарица у четвртој песми циклуса преселила у постојање на другој страни ваздуха, и успон песничког субјекта на зидине града степеницама „што спајају чистине / Затрпане озоном” (Лалић 1968: 64) задо- 
бија карактер успона до оностраности. Тек са узвишице на коју је тако доспео, он сагледава море, које „мрмља реченице” (Лалић 1968: 65), указујући на то да се истински смисао крије изван зидина града - не у материјалним траговима историје, већ у прошлости која сеже даље „од смисла тренутка” (Лалић 1968: $65)$ и открива се тек погледу који прониче дубље од појавног. Лирски субјекат одатле упире свој поглед не само даље од појавног већ и у историју даљу од оне „барокне”, коју превасходно отеловљује град обновљен после земљотреса, те испред себе види „море боје (...) сараценских застава”. У овој слици крије се алузија на арапску опсаду Дубровника, 867. године - на историјски догађај који задире у оне слојеве историје који, спрам сјаја ренесансног и барокног Града, често остају скрајнути. Истовремено, „реченице, удаљене / Од смисла тренутка што их ослушкује” (Лалић 1968: 65) мотив су који може сугерисати и удаљавање у смеру супротном од оног окренутог ка прошлости још дубљој од те „барокне", посведочене појавним обликом Града. Наиме, у односу на садашњост која ослушкује, удаљавање може бити управљено и ка будућности. У таквој констелацији ствари, ову посланицу, управо адресату из будућности, упућује адресант који, шетајући стварним Дубровником, у актуелном тренутку ослушкује сигнале његовог наслеђа.

Проговарање песничког субјекта из хабитуса Богородице, која песму Порmaл: Пиета почиње стихом „Клизиш ми са колена, век по век” (Лалић 1968: 66), не ослања се само на предтекст устаљене иконографске представе мајке божје која на крилу држи тело свога мртвог сина, већ и на евокацију историјске судбине рељефа који краси портал Фрањевачког самостана у Дубровнику. Пунији смисао слици вековног клизнућа Христа из мајчиног наручја даје податак да је премештање првобитне, ренесансне богомоље из простора ван градских зидина у његову унутрашњост, било праћено низом рушења и безуспешних покушаја поновног зидања, као и чињеница да је овај рељеф чудесно преживео разарање цркве у великом земљотресу, да би касније био пренет на нову, барокну грађевину. Како је у Лалићевој поезији вечно „само боље огледало за нашу пролазност” (Микић, 1996: 90, курзив - Ј. П.), у суочавању са чињеницом да је и ванвременска лепота каменог портала који приказује Богородицу и Христа како тамне „као дно огледала / Окренутог празнини” (Лалић 1968: 66), пуком игром случаја преживела земљотрес, освешћује се човекова пролазност. У том смислу, Лалић се служи детаљем из локалне историје Града да расветли универзално питање људске егзистенције.

Песма Пустијерна, чији наслов евоцира археолошки локалитет са остацима средњовековне палате, такође спада у ред оних обликованих помоћу мотива шетње. Иако је поменута палата једна од грађевина које нису обновљене после 1667. године, контемплативни субјекат традицију доживљава са једнаком пуноћом без обзира на то што за њено реактуализовање нема видљиве подстицаје. Чињеница да је мотив рушевина палате само имплициран, условљава да традиција у овој песми постоји пре свега на нивоу трага. Отуда се у тексту јављају они мотиви који у модерној поезији готово амблематски представљају присут- 
ност одсутнога - звук, глас и мирис, али и Лалићеви самосвојни симболи исте провенијенције: у првом реду симбол простораิ који не постоје материјално, већ искључиво у сфери контемплације, у какве спада врт „досељен после речи (...) на развалине давног говора”, за којим песничко ,,ја” трага по Пустијерни. Искуство сусрета са траговима прошлости лирског субјекта чини зрелијим, будући да се из „перипатетичког” промишљања прошлости „враћа нагло старији” (в. Лалић 1968: 67). Стога и у овој песми локалитет од првокласног значаја за културну историју Дубровника има функцију подстицаја на певање о једној од великих тема модерне лирике - о динамичној природи личности.

Песма Ахасфер у Дубровнику враћа се теми приласка граду. Међутим, док се у песми Путник пред Дубровником, јануара тематизује само улазак у град, субјекат на почетку ове песме улази кроз Врата од Пила, западну капију града, и на крају излази на источна Врата од Плоча. На свом путу се, по свему судећи, креће дуж Плаце, будући да пролази „чесму на тргу”, да би пре изласка стигао до зида, иза којег је море (в. Лалић 1968: 68). ${ }^{6}$ У том смислу, ова песма не говори о приласку, већ о проласку градом, а итинерар лирског субјекта спаја само најзначајније локалитете старог градског језгра, чиме се наговештава тема која ће бити предмет много директније песничке обраде у Лалићевој антологијској Плавој гробници (Јовановић 1997: 48) - тема туризма. Површан туристички однос према материјалној култури сугерисан је не само великим бројем локалитета обухваћених овом маршрутом и опходаних у једном маху, већ и мотивом „камених степеница” (Лалић 1968: 68). Исказ да су субјекта ове песме такве лестве „Водиле до зида” (Лалић 1968: 68, курзив - Ј. П.) нема карактер пуког референцијалног означавања чињенице да је трг Лужа, којим се Плаца завршава, у непосредној близини мора. Он супротставља површно ходање контемплативном шетағу, у којем се, као у песми Дубровачке зидине, отварају ваздушне, оностране „степенице што спајају чистине / Затрпане озоном” (Лалић 1968: 64) и воде у пределе метафизичког. Отуда наслов песме, реминисценцијом на Ахасфера, сугерише да пролазник који не трага за ониме што се налази иза појавног, туриста, бива и сам, попут овог вечитог луталице, осуђен да никада не стигне на одредиште истинског смисла ствари.

Последња песма циклуса, Похвала Дубровнику, „сумира” слику Града Светог Влаха као појаве јединствене у симултаности свог појавног и онтолошког претрајавања, какво је сплет историјских околности ускратио Цариграду и Смедереву. ${ }^{7}$ Његова „виталност” најпре се сугерише посредством мотива трајања у језику, који опстаје „у устима летописаца” попут „меда у деблу” (Лалић 1968: 69). Посебан онтолошки статус Града, на различите начине уобличен у осталим песмама циклуса, у овом се тексту експлицира апосторфирањем Дубровника

${ }^{6}$ Главна дубровачка улица не спаја Врата од Пила и Врата од Плоча, већ „избија“ на трг Лужа, иза којег је, на другој страни бедема, Стара лука. Упркос томе, Плаца представља најкраћи пут од источне до западне стране града, те се може рећи да она, у практичном смислу, заиста спаја две градске капије.

${ }^{7}$ „Пад” ових градова тема је извесног боја Лалићевих песама (в. Јовановић 1997: 31-32, 38-39). 
као „твари нестварне” (Лалић 1968: 69), чиме се на још један начин наглашава двострукост његовог симултаног материјалног и метафизичког постојања. Последња строфа појашњава начин егзистирања Дубровника у оностраности: изједначен са „шаком чисте шљаке”, са појмом из сфере материјалног, он се „надграђује (...) у новим устима” и „као мера се враћа” (Лалић 1968: 69). Тиме се указује да стари Дубровник траје у реактуализовању традиције и, будући квалификован као „лепота без упоредног речника” (Лалић 1968: 69), постаје висока мера за лепо.

Након сагледавања поетичко-стилске слојевитости циклуса Дубровник зимска прича, могуће је издвојити два песникова начелна приступа транспоновању дубровачке традиције. У једном броју песама, „дубровачке теме” постављене су у центар песникове пажње, ${ }^{8}$ бивајући гравитациона језгра за друге мотивско-тематске елементе. Семантика тако обликованих текстова почива примарно на грађењу слике Дубровника као појаве јединствене у свом материјалном и онтолошком одолевању времену, која следи поетичку линију зачету у делима Луја и Ива Војновића. Поред ових, постоје и оне песме у којима су мотиви дубровачких локалитета и евокације елемената културне историје Града стављени у функцију певања о другим темама које спадају у Лалићев сржни мотивско-тематски корпус. У том смислу, Иван В. Лалић није изузет из општих тенденција својих савременика и познијих аутора који су ступали у дијалог са дубровачком традицијом. Након њега су и Данило Киш у драмском (Ковачевић 2013: 179-181), а Милорад Павић (в. Бојовић 2001: 49-62; Бојовић 2010: 183190), Славомир Настасијевић, Горан Петровић (в. Бојовић 2001: 49-62), Саша Хаџи Танчић, и Радослав Братић (в. Бојовић 2009в: 209-220) у прозном облику, оживљавали дубровачку традицију - или њеним постављањем у тематско тежиште својих дела, или функционализовањем њених одабраних аспеката при грађењу особених уметничких светова својих дела. На овај начин, у савременој српској књижевности наставља се линија стваралаца XIX и XX века који су културну повест старог Дубровника баштинили и уграђивали је у темеље свог опуса.

\section{ЛИТЕРАТУРА}

Алексић 2015: М. Алексић, Песништво Ивана В. Лалића и књижевна традиција, Научни састанак слависта у Вукове дане, 45, 213-222.

Бојовић 1983: З. Бојовић, Дубровачке теме у делима српских романтичара, Научни састанак слависта у Вукове дане, 12/2, 245-260.

Бојовић 1994: 3. Бојовић, Занимање Иве Андрића за дубровачке теме, $\mathrm{Ha}$ учни састанак слависта у Вукове дане, 22/1, 255-267.

${ }^{8}$ У ову групу песама убрајамо следеће: Путник пред Дубровником, јануара, Гласови:Finis reipublicae, Морнарица, Свети Влахо, Каменари и Похвала Дубровнику. 
Бојовић 1996а: З. Бојовић, Монографија Јована Дучића о Сави Владиславићу Рагузинском, у: П. Палавестра (ур.), О Јовану Дучићу, поводом педесетогодишњице смрти, књ. 85, Научни скупови САНУ, Београд: Одељење језика и књижевности, 193-200.

Бојовић 1996б: З. Бојовић, Роман Гундулићев Осман Душана Богосављевића, Книжевност и језик, 3-4, 129-137.

Бојовић 1996в: З. Бојовић, Маројица Кабога Матије Бана и дубровачка историја, Научни састанак слависта у Вукове дане, 25/1, 77-85.

Бојовић 1997: 3. Бојовић, Најстарији дубровачки ренесансни ћирилични стихови у песмама Милана Савића и Љубомира Симовића, у: М. Матицки и др. (ур.), Из књижевности: зборник радова у част Предрага Палавестре, Београд: ИКУМ, 109-114.

Бојовић 2001: 3. Бојовић, Стари Дубровник и Дубровчани у савременим српским историјским романима, у: М. Стојановић, Н. Лаиновић-Стојановић, Кьижевност и историја, IV, Историјски роман код Словена, Ниш: Центар за научна истраживања САНУ и Универзитета, Студијска група за српски језик и књижевност Филозофског факултета; Београд: Славистичко друштво Србије, 49-62.

Бојовић 2005a: 3. Бојовић, Дубровник - зимска прича Ивана В. Лалића $u$ Кључеви Светог Влаха Љубомира Симовића, Научни састанак слависта у Вукове дане, 34/2, 367-373.

Бојовић 2005б: 3. Бојовић, Стари Дубровник у виђењима Милоша Црњанског, Годишьак Катедре за српску књижевност са јужнословенским књижевностима, I, Београд, 167-174.

Бојовић 2007a: 3. Бојовић, Из књижевне оставштине Андре Гавриловића, Дубровачке арабеске - По Дубровнику, у: М. Матицки (ур.), Признање професору Слободану Ж. Марковићу, Београд: ИКУМ, Вукова задужбина, Задужбина „Десанка Максимовић”, 139-146.

Бојовић 2007б: 3. Бојовић, Дубровник XVI века у виђењу Александра Видаковића у роману Марин Сорго, Митолошки зборник, 17, Рача - Београд, 239-247.

Бојовић 2009а: 3. Бојовић, Дубровачке легенде у новелама Вида Вулетића Вукасовића, Научни састанак слависта у Вукове дане, 38/2, 189-196.

Бојовић 2009б: 3. Бојовић, Све за љубав науке с мученицом Цвијете Зузорића, Кьижевност и језик, LVI/1-2, 137-146.

Бојовић 2009в: З. Бојовић, Дубровник изван Дубровника, Радост приповедања Саше Хаџи Танчића и Путеви соли Радослава Братића, Кюижевност $и$ језик, LV/3-4, 209-220.

Бојовић 2010: З. Бојовић, Контрапункт времена - дубровачке приче Милорада Павића, у: Стари Дубровник у српској књижевности, Београд: Службени гласник, 183-190.

Бојовић 2014: 3. Бојовић, Историја дубровачке књижевности, Београд: СКЗ. 
Веселиновић 2012: С. Веселиновић, Преводилачка поетика Ивана В. Лалића, Нови Сад: Академска књига.

Војновић 1962: L. Vojnović, Kratka istorija Dubrovačke republike, New York: Marica Schidolf-Vojnović (izdavač).

Војновић 1924: Л. Војновић, Дубровачке елегије, Дубровник: Књижара Ј. Тошовића.

Вуловић 1890: С. Вуловић, Бранко Радичевић: прилог историји нове српске књижевности, Београд: Краљевска српска државна штампарија, 136-138.

Јовановић 1996: А. Јовановић, Песник зрелог лета, у: Д. Хамовић (ур.), Иван В. Лалић, песник: зборник, Краљево: Повеља, 97-112.

Јовановић 1997: А. Јовановић, Иван В. Лалић или висока мера песничке уметности, у: Иван В. Лалић, Време, ватре, вртови, Београд: ЗУНС, 9-83.

Ковачевић 2013: С. Ковачевић, Биографија Држића чека свог синеасту, Сцена: часопис за позоришну уметност, 49/1, Нови Сад: Стеријино позорје, 179-18.

Константиновић 2002: 3. Константиновић, Интертекстуална компаратистика, Београд: Народна књига.

Лалић 1968: И. В. Лалић, Круг, Београд: Нолит.

Летић 2000: Б. Летић, Алекса Шантић и Дубровник, у: Р. Вучковић (ур.), Алекса Шантић, живот и дјело, зборник радова, књ. III, Зборници и монографије, Бања Лука - Српско Сарајево: АНУРС, Одјељење књижевности и умјетности, 113-142.

Летић 2005: Б. Летић, Трагови дубровачког књижевног барока у историјским приповеткама Стевана Сремца, Научни састанак слависта у Вукове дане, 34/2, 177-184.

Мартиновић 1938: А. Мартиновић, Утицај дубровачке поезије на Јована Илића, ЛМС, 112/ 349, Нови Сад, 299-301.

Микић 1996: Р. Микић, Слика убрзање и огледало, у: Д. Хамовић (ур.), Иван В. Лалић, песник: зборник, Краљево: Повеља, 69-95.

Новак 2005: S. Prosperov Novak, Volite li Dubrovnik?, Zagreb: VBZ.

Петаковић 2012: С. Петаковић, Помени Дубровника у епској фолклорној традицији, ПКЈИФ, LXXVIII/1-4, 113-126.

Петаковић 2013: С. Петаковић, Мотив браве дубровачке у епским народним песмама, Прилози за књижевност, језик, историју и фолклор, LXXIX, $31-46$.

Петаковић 2016а: С. Петаковић, Поетизовање историјске потке у Дубровачким елегијама Луја Војновића, Научни састанак слависта у Вукове дане, 45/2, 99-105.

Петаковић 2016б: С. Петаковић, Дубровник у путописима крајем XIX и XX века, Зборник Матице српске за книжевност и језик, LXIV/2, Нови Сад, 353-364. 
Петаковић 2017: С. Петаковић, Дубровник у есејима Луја Војновића, $\mathrm{Ha}$ учни састанак слависта у Вукове дане, 46/2, 63-69.

Петаковић 2020: С. Петаковић, Песничка кондензација историје у драми Кључеви Светог Влаха Љубомира Симовића, у: С. Шеатовић и др. (ур.), Књижевност, култура, идентитет: међународни зборник радова у част проф. др Јована Делића, Београд: ИКУМ, 779-787.

Делић 2007: J. Делић, Лалићев дијалог са савременом српском поезијом ка експлицитној поетици Ивана В. Лалића, у: А. Јовановић (ур.), Постсимболистичка поетика Ивана В. Лалића. Зборник радова, Београд: ИКУМ, Учитељски факултет, 19-58.

Христић 1994: Ј. Христић, Иван В. Лалић, у: Есејu, Нови Сад: Матица српска, 85-100.

Шеатовић-Димитријевић 2007: С. Шеатовић-Димитријевић, Лалићево море, од медитеранске чулности до старозаветног страха, у: А. Јовановић (ур.), Постсимболистичка поетика Ивана В. Лалића. Зборник радова, Београд: ИКУМ, Учитељски факултет, 133-160.

Jana S. Petrović

THE POETICAL EVOCATION OF DUBROVNIK IN DUBROVNIK - A WINTER'S TALE, A LYRIC SEQUENCE BY IVAN V. LALIĆ

The paper examines the ways of evoking the literary, historical, and cultural heritage of Old Dubrovnik in the lyric sequence Dubrovnik - A Winter's Tale, by Ivan V. Lalić, as well as the meaning and function of said heritage in each poem. The poet's dialogue with tradition is reviewed in the context of Serbian $19^{\text {th }}$ and $20^{\text {th }}$ century authors' revival of interest in Dubrovnik's tradition.

Keywords: Ivan V. Lalić, Dubrovnik - A Winter's Tale, Dubrovnik, $19^{\text {th }}$ century Serbian literature, $20^{\text {th }}$ century Serbian literature, Dubrovnik literature, culture. 